\title{
Seroprevalence and economic impact of eradicating zoonotic brucellosis in Malaysia : A case study of Melaka state of Malaysia
}

\author{
Pwaveno H. Bamaiyi, Noor S. Abd-Razak , Mohamed A. Zainal \\ Universiti Putra Malaysia; 1. Dept of Veterinary Services Melaka, Malaysia \\ Corresponding author: Pwaveno H Bamaiyi, email:phbamaiyi@yahoo.com \\ Received: 25-11-2011, Accepted: 06-01-2012, Published Online: 17-04-2012 \\ doi: $10.5455 /$ vetworld.2012.398-404
}

\begin{abstract}
Aim: A study was carried out to elucidate the seroprevalence of brucellosis in small and large ruminants in Melaka state of Malaysia and estimate the economic impact of zoonotic brucellosis in Malaysia using available data.

Materials and Methods: Data was collected during culling exercises by the Department of Veterinary Services of Malaysia as a result of surveillance using CFT as a confirmatory test for brucellosis.

Results: The average compensation in 4 years per district of Melaka state was RM12248.875(USD 3874.75) and the total compensation paid in 4 years was RM146,986.50(USD45,865.24) with year 2009 having the highest compensation amount of RM58,914.40(USD18,383.48). The estimated total economic losses due to brucellosis stands at about RM200,607,946.80 (USD 62,926,060.84) in a year for the whole of Malaysia. The odds of brucellosis in large ruminants (cattle/buffaloes) was significantly 1.6 times more compared to small ruminants (goats/sheep) in Melaka $(\mathrm{P}<0.0001$; C.I. 1.41, 1.81) during the 4 year period. Average 4 year total seroprevalence for brucellosis in Melaka was significantly higher in 2010 than previous years with a rate of $7.78 \%(\mathrm{P}<0.05$; Phi=0.025). Mass importation of livestock may be contributing in complicating the brucellosis situation.

Conclusion: Considering the economic importance of brucellosis and its epidemiological importance to public health more needs to be done to ensure successful eradication of the zoonotic disease in Malaysia.

Key words: Brucellosis, Brucella, Economic Impact, Seroprevalence, Zoonotic
\end{abstract}

To cite this article: Bamaiyi PH, Abd-Razak NS, Zainal MA (2012) Seroprevalence and economic impact of eradicating zoonotic brucellosis in Malaysia : A case study of Melaka state of Malaysia, Vet World, 5(7): 398-404, doi: 10.5455/vetworld.2012.398-404

\section{I ntroduction}

Brucellosis is a bacterial zoonotic infection caused by members of the Brucella genus. Currently there are eight known species in terrestrial animals and 2 in marine animals. The species in terrestrial animals include: B. abortus, B.melitensis, B. suis, B. neotomae, B. canis, B. ovis, B. microti and B. inopinata $[1,2,3,4]$. The species in marine mammals include: $B$. ceti and $B$. pinnipedialis [5]. The most common domestic animals affected by brucellosis are Cattle, Buffaloes, Goats, Sheep and Pigs [4]. The economic impact of brucellosis is enormous and varies from country to country and from region to region. In Latin America annual losses are estimated at $\$ 600$ million and in the U.S.A. the cost of abortion and reduced milk production in 1952 alone were put at $\$ 400$ million [4,6].

Brucellosis is still endemic in most parts of the world in both humans and animals except a few countries like Australia, Canada, Cyprus, Finland, Denmark, The Netherlands, United Kingdom, Norway, Sweden and New Zealand where bovine brucellosis has been eradicated [4]. It has been reported in different countries in Asia including Pakistan [7], Sri Lanka [8], India [9], China[10], Mongolia [11] and other parts of Asia [12].There are about 500,000 new human cases of brucellosis reported annually worldwide making it the commonest zoonosis [4].

In Malaysia, Brucella was first isolated in 1950 and the government embarked upon an eradication program for brucellosis in Cattle, Buffaloes, Goats and Sheep since 1978 with full implementation and compensation scheme taking off in 1982 [13,14] Losses usually arise from the following: loss of foetus, decreased milk yield, interference with breeding system, infertility, joint infections, weakling offsprings, condemnation of infected animals, threat of reduced 
Seroprevalence and economic impact of eradicating zoonotic brucellosis in Malaysia : A case study of Melaka state

Table-A. Compensation for Cattle and Buffaloes

\begin{tabular}{lllll}
\hline Species & Category & Partial Compensation(RM) & Full Compensation(RM) & Means of Identification \\
\hline Cattle & calves & $530($ USD166.25) & 800 (USD250.94) & No permanent incisors \\
& adult beef cattle & $800($ USD250.94) & $1600($ USD501.88) & \\
& adult dairy cattle & $1000($ USD313.68) & $2000($ USD627.35) & Breed records \\
\multirow{3}{*}{ Buffaloes } & pedigree & $2000($ USD627.35) & $4000($ USD1254.71) & No permanent incisors \\
& calves & $530($ USD166.25) & $800($ USD250.94) & \\
& adult & $1000($ USD313.68) & $2000($ USD627.35) & Breed records \\
\hline
\end{tabular}

Source: Department of Veterinary Services, Malaysia

market access, disease in man, national administrative costs of control and eradication programmes. Administrative costs for attempted eradication of bovine brucellosis 26 years ago were estimated to have costed the Malaysian government $\$ 450,000$ in a single year [15].

Malaysia has about 18,270 farms already entered into the official register as of 2010 and the register is still being updated and many thousands of unregistered farms, and the total estimated population of Livestock as of 2010 is as follows: Buffaloes126,478, Cattle-912,230, Goats-545,682, Sheep134,408 and Swine-1,821,663 [16]. The average total seroprevalence of brucellosis in animals in Malaysia varies from $0.17 \%$ to $2.43 \%$ in goats [17] and $1.52 \%$ to $6.73 \%$ in Cattle and Buffaloes [18] in different states of the federation. Human brucellosis has also been reported in farmers, veterinary technical staff and other people who work closely with animals in Malaysia with seroprevalence ranging from 0 to $14.29 \%[17,19]$.

Malaysia has eradication and stamping out policy for brucellosis which does not allow for vaccination of animals against brucellosis [20]. The eradication policy involves routine testing of ruminant livestock by the Department of Veterinary Services using various serological screening tests including Enzyme Linked Immuno-Sorbent Assay (ELISA), Rose Bengal Plate Test (RBPT) and the confirmatory Complement Fixation Test (CFT). All animals that test positive with the confirmatory CFT are culled and some measure of compensation is paid to the farmers affected [13, 17].

Melaka (a.ka. Malacca) $\left(02^{\circ} 15^{\prime} \mathrm{N}\right.$ and $\left.102^{\circ} 15^{\prime} \mathrm{E}\right)$ is one of the smallest states in Malaysia with only 3 districts but is key to understanding Malaysia thereby earning the designation of historical state and the capital Melaka is called the historical city of Malaysia. It has a rich cultural diversity and a flourishing livestock industry. The human population is about 761000 out of the total population of Malaysia which is about 27,895000 [21].
This study was undertaken to elucidate the seroprevalence of brucellosis in Melaka state of Malaysia from year 2007 to 2010, the economic impact of the infection using Melaka (data for other states was not available) as a case study to estimate roughly the economic impact of this important zoonotic infection in Malaysia.

\section{Materials and Methods}

The Department of Veterinary Services of Malaysia carries out routine monitoring and surveillance by screening for brucellosis in Malaysia in different farms. About $10 \mathrm{ml}$ of blood was collected from the jugular veins for screening in anticoagulant bottles. The collected blood was tested for brucellosis at the Serology unit of the National Veterinary Research Institute, Ipoh, Malaysia using the confirmatory Complement Fixation Test (CFT) according to the method of Alton et al [22]. A total of 17,661 blood samples were taken from year 2007 to 2010 made up of 13,589 from small ruminants (goat and sheep) and 4,072 from large ruminants (buffaloes and cattle). Data generated was analysed using IBM SPSS version 19 and differences were considered significant at $95 \%$ confidence level [23]. Animals that were confirmed positive were culled in accordance with the eradication policy at the discretion and schedule of the Department of Veterinary Services. Positive Goats and Sheep were slaughtered and buried deep with lime in the ground and for positive Cattle and Buffaloes the offals were usually removed at slaughter and buried but the meat (muscles) are left at the discretion of the veterinary personnel. Compensation was later (period ranges from a few months to several months) paid to farmers at the official rate of RM5.60 (USD1.77) per $\mathrm{kg}$ for goats/sheep and for cattle/Buffaloes as shown in Table-A.

The online currency converter [24] was used for converting to United States dollars (USD) equivalents of the local currency the Malaysian Ringgit (RM). The average compensation amount for cattle and buffaloes was used for calculating for the total nationwide 


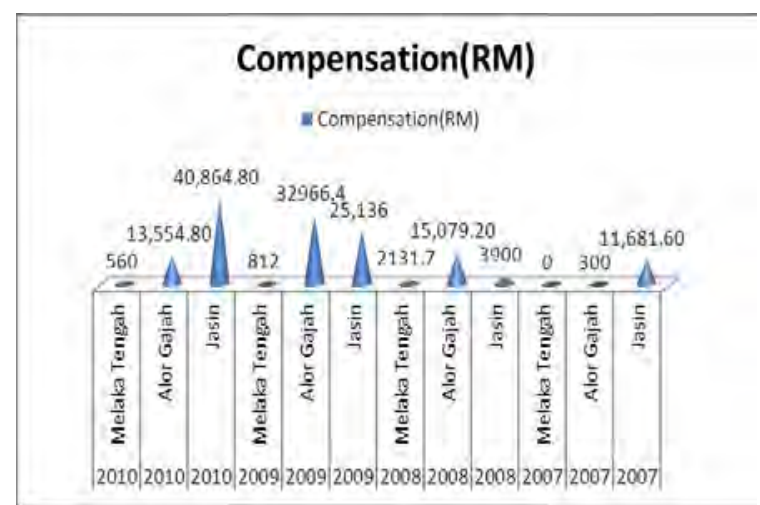

Figure-1: chart showing the amount of compensation already paid by government in the 3 districts of Melaka

compensation. We estimated the given compensation averagely for all animals based on market trends, transport and inflation to be grossly about $60 \%$ of actual cost to the farmer for purchase. Some information were gathered from interviews and interactions with the local farmers and used in estimation. Since the weight of goats and sheep are highly variable depending on age, breed, sex and other features we fixed the average value as $30 \mathrm{~kg}$ for the purpose of our economic impact calculations. National seroprevalence rate for brucellosis in goats was taken as $0.95 \%$ [25] and was used similarly for sheep to determine the number of goats and sheep that could be culled and compensated with the present population of sheep and goats in Malaysia. For national seroprevalence rate for bovine brucellosis, $5.0 \%$ was used for cattle and $1.6 \%$ for buffaloes [18]. The current available livestock population for 2010 (table 3) was used [16].

\section{Results}

Figure-1 shows the compensation already paid out to farmers of positive farms after confirmation of brucellosis and culling of the animals had taken place in Melaka state of Malaysia with three administrative districts. The average compensation in 4 years per district of Melaka state is RM12248.875 (USD 3874.75 ) and the total compensation paid in 4 years was RM146,986.50(USD45,865.24) with year 2009 having the highest compensation amount of RM 58,914.40 (USD18,383.48).

The large ruminants (cattle and buffaloes) had a significantly higher seroprevalence rate than the small ruminants (goats and sheep) during the 4 year period (figure 2 and table 1). Average 4 year total seroprevalence for brucellosis in Melaka was significantly higher in 2010 with $7.78 \%$ (figure-3 and table-2).

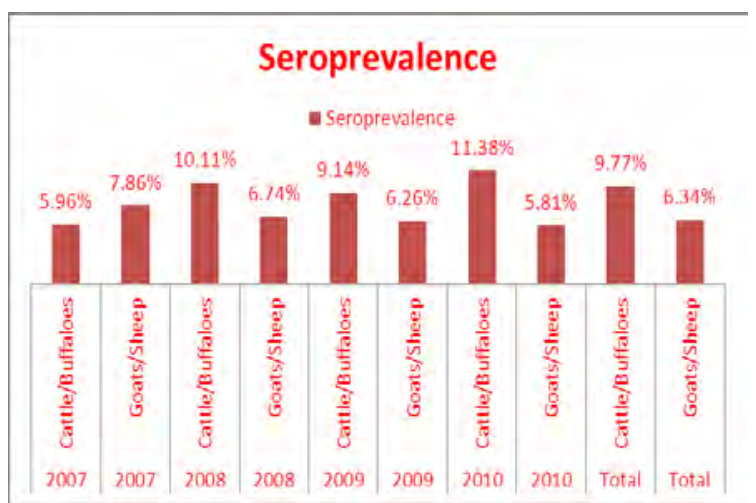

Figure-2: Seroprevalence rates for large and small ruminants in Melaka from 2007-2010

Table 1: Species Status Cross tabulation

\begin{tabular}{lllll}
\hline Species & & \multicolumn{2}{c}{ Status } & Total \\
& & Negative & Positive & \\
\hline CATTLE/ & Count & 398 & 3674 & 4072 \\
BUFFALOES & Expected Count & 290.3 & 3781.7 & 4072.0 \\
& \% within SPECIES & $9.8 \%$ & $90.2 \%$ & $100.0 \%$ \\
& \% within STATUS & $31.6 \%$ & $22.4 \%$ & $23.1 \%$ \\
GOATS/SHEEP & \% of Total & $2.3 \%$ & $20.8 \%$ & $23.1 \%$ \\
& Count & 861 & 12728 & 13589 \\
& Expected Count & 968.7 & 12620.3 & 13589.0 \\
& \% within SPECIES & $6.3 \%$ & $93.7 \%$ & $100.0 \%$ \\
Total & \% within STATUS & $68.4 \%$ & $77.6 \%$ & $76.9 \%$ \\
& \% of Total & $4.9 \%$ & $72.1 \%$ & $76.9 \%$ \\
& Count & 1259 & 16402 & 17661 \\
& Expected Count & 1259.0 & 16402.0 & 17661.0 \\
& \% within SPECIES & $7.1 \%$ & $92.9 \%$ & $100.0 \%$ \\
& \% within STATUS & $100.0 \%$ & $100.0 \%$ & $100.0 \%$ \\
& \% of Total & $7.1 \%$ & $92.9 \%$ & $100.0 \%$ \\
\hline
\end{tabular}

(Odds Ratio for Species: Cattle/Buffaloes/Goats/Sheep $=1.60$ C.I. 1.41, 1.81; $\mathrm{Phi}=0.056$ ) $\mathrm{P}<0.0001$ (Disease status is significantly dependent on species but relationship is negligible)

\section{Table-2: Year Status Cross tabulation}

\begin{tabular}{lllll}
\hline Year & & \multicolumn{2}{c}{ Status } & Total \\
& & Negative & Positive & \\
\hline 2007 & Count & 95 & 1321 & 1416 \\
& Expected Count & 100.9 & 1315.1 & 1416.0 \\
& \% within Year & $6.7 \%$ & $93.3 \%$ & $100.0 \%$ \\
& \% within Status & $7.5 \%$ & $8.1 \%$ & $8.0 \%$ \\
\multirow{5}{*}{2008} & \% of Total & $.5 \%$ & $7.5 \%$ & $8.0 \%$ \\
& Count & 353 & 4318 & 4671 \\
& Expected Count & 333.0 & 4338.0 & 4671.0 \\
& \% within Year & $7.6 \%$ & $92.4 \%$ & $100.0 \%$ \\
& \% within Status & $28.0 \%$ & $26.3 \%$ & $26.4 \%$ \\
2009 & \% of Total & $2.0 \%$ & $24.4 \%$ & $26.4 \%$ \\
& Count & 400 & 5892 & 6292 \\
& Expected Count & 448.5 & 5843.5 & 6292.0 \\
& \% within Year & $6.4 \%$ & $93.6 \%$ & $100.0 \%$ \\
& \% within Status & $31.8 \%$ & $35.9 \%$ & $35.6 \%$ \\
2010 & \% of Total & $2.3 \%$ & $33.4 \%$ & $35.6 \%$ \\
& Count & 411 & 4871 & 5282 \\
& Expected Count & 376.5 & 4905.5 & 5282.0 \\
& \% within Year & $7.8 \%$ & $92.2 \%$ & $100.0 \%$ \\
& \% within Status & $32.6 \%$ & $29.7 \%$ & $29.9 \%$ \\
Total & \% of Total & $2.3 \%$ & $27.6 \%$ & $29.9 \%$ \\
& Count & 1259 & 16402 & 17661 \\
& Expected Count & 1259.0 & 16402.0 & 17661.0 \\
& \% within Year & $7.1 \%$ & $92.9 \%$ & $100.0 \%$ \\
& \% within Status & $100.0 \%$ & $100.0 \%$ & $100.0 \%$ \\
& \% of Total & $7.1 \%$ & $92.9 \%$ & $100.0 \%$ \\
\hline
\end{tabular}


Table-3: Malaysia: Livestock Population, 20052010

\begin{tabular}{|c|c|c|c|c|c|c|}
\hline Livestock Type & 2005 & 2006 & 2007 & 2008 & 2009 & 2010P \\
\hline \multicolumn{7}{|c|}{ B uffalo } \\
\hline Peninsula Malaysia & 79,495 & 79,044 & 80,931 & 79,661 & 74,979 & 74,102 \\
\hline Sabah & 44,500 & 40,929 & 42,157 & 43,422 & 44,200 & 44,642 \\
\hline Sarawak & 9,237 & 8,965 & 7,687 & 8,146 & $7,973 \mathrm{P}$ & 7,734 \\
\hline Total & 133,232 & 128,938 & 130,775 & 131,229 & 127,152 & 126,478 \\
\hline \multicolumn{7}{|c|}{ Cattle } \\
\hline Sabah & 45,170 & 87,122 & 89,085 & $89,825 \mathrm{R}$ & R 93,231 & 95,096 \\
\hline Sarawak & 12,375 & 12,918 & 11,919 & 12,964 & $13,983 \mathrm{P}$ & P 14,352 \\
\hline \\
\hline Peninsula Malaysia & 247,460 & 293,871 & 373,319 & 419,720 & 452,467 & 483,268 \\
\hline Sabah & 30,250 & 44,410 & 45,742 & 45,742 & 47,110 & 47,779 \\
\hline Sarawak & 9,960 & 11,146 & 9,202 & 12,018 & $14,656 \mathrm{P}$ & P 14,635 \\
\hline Total & 287,670 & 349,427 & 428,263 & 477,480 & 514,233 & 545,682 \\
\hline \multicolumn{7}{|l|}{ Sheep } \\
\hline Peninsula Malaysia & 109,898 & 111,103 & 122,106 & 125,931 & 130,723 & 129,359 \\
\hline Sabah & 1,890 & 1,950 & 1,970 & 1,989 & 2,009 & 2,029 \\
\hline Sarawak & 4,134 & 3,334 & 1,912 & 3,338 & $3,553 \mathrm{P}$ & 3,020 \\
\hline & 115,922 & 116,387 & 125,988 & 131,258 & 136,285 & 134,408 \\
\hline \multicolumn{7}{|l|}{ Swine } \\
\hline Peninsula Malaysia & $1,528,942$ & $1,514,170$ & $1,441,036$ & $1,407,195$ & $51,401,190$ & $01,404,168$ \\
\hline Sabah & 120,000 & 91,091 & 82,200 & 105,075 & 83,972 & 77,926 \\
\hline Sarawak & 386,705 & 423,858 & 496,881 & 216,037 & 346,146 & P339,569 \\
\hline Total & $2,035,647$ & $2,029,119$ & $2,020,117$ & $1,728,307$ & $7 \quad 1,831,308$ & 8 1,821,663 \\
\hline
\end{tabular}

P: Provisional, R : Revised Source: Department of Veterinary Services of Malaysia

National estimate: Average compensation amount for 1 cattle was estimated to be RM1, 591.25 and this multiplied by the total number of cattle to be culled using 5.0\% national seroprevalence rate as of the population of cattle in 2010 (table 3) will be RM 72, 579,299.38.

Average compensation for 1 buffalo was RM $1,971.67$ and computing for the total population of buffaloes with the national prevalence rate of $5.0 \%$ will be RM3, 989,966.05.

Average compensation for the goats at approved RM5.60 per $\mathrm{kg}$, computing for the national seroprevalence rate of $0.95 \%$ will be RM870, 908.47. Average compensation for sheep at approved RM5.60 per $\mathrm{kg}$, computing for the national seroprevalence rate of $0.95 \%$ will be RM 214,515.17.

Total compensation expenditure by government on farmers will be: RM 72, 579,299.38(cattle) + RM3, 989,966.05(buffaloes) + RM870, 908.47 (goats) + RM $214,515.17$ ( s h e e p ) = R M 7 7,654,689.07 (USD24,358,475.16). This amount RM77,654,689.07 (USD24,358,475.16) covers averagely based on market values which are highly variable only about $60 \%$ of the original cost of purchase to farmers without adding the cost of production. That leaves out about $40 \%$ cost loss to farmers.

Calculating the $40 \%$ unpaid cost to farmers will be RM77, 654,689.07 ×0.4(40\%) $\div 0.6(60 \%)=$ RM51, 769,792.71(USD16, 238,983.44).

Therefore, Compensation cost+left out compensation=actual compensation for cost of purchase of

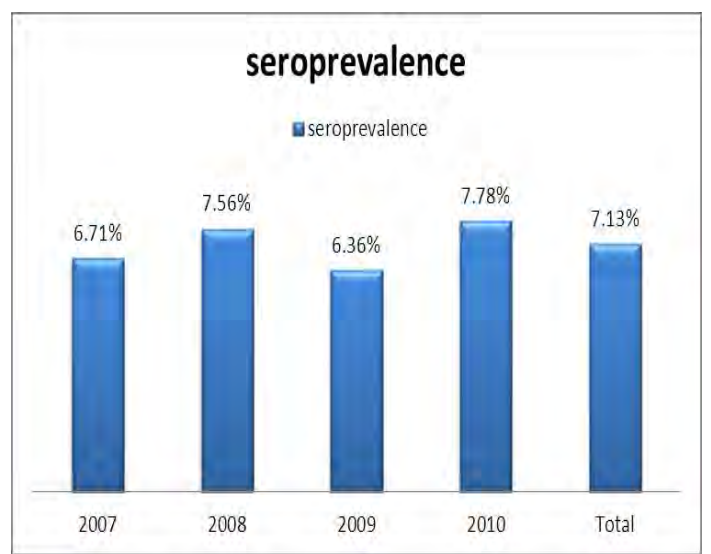

Figure-3: Yearly total Seroprevalence rates pattern for Melaka state, Malaysia from 2007-2010

livestock. This will be: RM77,654,689.07 + RM $51,769,792.71=$ RM 129,424,481.8 (money actually spend by farmers to purchase animals).

Taking $5 \%$ of this as money spent on logistics and administration such as wages, allowances, transport, materials, laboratory costs, etc.by the eradication officers and allied committees: $5 \%$ of RM $129,424,481.8$ will be=RM 6,471,224.09.

Based on calculations of cost of production for a typical farm we arrived at a production cost of approximately $50 \%$ of cost of purchase of the animal in a year:

Computing using the total cost of purchase of RM 129,424,481.8: $50 \%$ of RM 129,424,481.8 = RM64,712,240.90.

Total amount in a year therefore is: RM 129,424,481.8 + RM 6,471,224.09 + Rm64,712, 240.90=RM200,607,946.80 (USD 62,926,060.84).

This amount RM200,607,946.80 (USD 62, $926,060.84)$ represents approximately the total loss due to brucellosis in Malaysia not taking into account the economic impact if human health is endangered or there is a bioterrorist attack using Brucella melitensis which is estimated to cost $\$ 477.7$ million per 100,000 persons exposed [26].

\section{Discussion}

The monetary compensation of farmers after culling is part of the test and slaughter policy to ameliorate the losses borne by farmers as a result of this policy which aims to eradicate brucellosis. The 
compensation amount shown is not a perfect representation of the actual compensation as some farmers will have to wait for an indefinite period sometimes after verification before they are given their compensation. More money was spend on compensation in year 2009 inspite of the fact that year 2010 had the highest seroprevalence. Records (unpublished data) indicated that for the same year 2010 many positive animals were not yet culled and hence the farmers could not be compensated since the compensation record only contains farmers already compensated after verification. The year 2010 has the highest prevalence rate of $7.78 \%$ in Melaka may be due to the increase in number of animals imported into the country as that year also has the highest number of livestock (see table 3 ) imported into Malaysia in the continuous effort for years to improve and increase the genetic pool of livestock in Malaysia [14] many of which are from endemic countries which may contribute to the increase in prevalence of brucellosis [27]. The addition of new animals has also been identified as a risk factor for brucellosis in a previous study in Jordan [28].

The odds of brucellosis in large ruminants in our study was 1.6 times compared to the small ruminants. The disease status was significantly associated with the species of animals but the relationship was negligible using the Guilford's rule of thumb [29] and likewise the association with year. That large ruminants had a significantly higher seroprevalence than the small ruminants disagrees with the findings of El Sherbini et al [30] who found sheep had the highest prevalence among livestock in a study in Egypt but agrees with the findings of Omer et al [31] in Eritrea, who found husbandry systems have effect on the prevalence of brucellosis and large ruminants had higher prevalence than small ruminants. In another study in Zambia large ruminants were also found to have higher seroprevalence than small ruminants [32]. It is worth noting that most farmers keep goats and sheep along with large ruminants which increases the odds of testing seropositive for brucellosis among Cattle and Buffaloes 6.32 times [33]. The keeping of sheep in addition to goats has been identified as risk factor for brucellosis increasing the risk by upto 6 times compared to keeping only goats [34]. The control of the disease in humans will depend to a great extent on how much of it is controlled in livestock [35] and its presence in livestock in Malaysia raises serious public health concerns for Malaysia and the Asia Pacific region. Perhaps, instead of just applying the test and slaughter policy that is yet to eradicate brucellosis in Malaysia, the Egyptian 2 fold approach of test and slaughtering the positive animals and then vaccinating the livestock population [36] which is not being practiced in Malaysia may be a better approach.

With a GDP real growth rate of 7.2\% [37] which is one of the best in Asia, Malaysia's economy would even be better without brucellosis and its potentials for greater losses to the economy. With over $\$ 62$ million annually which is lost to brucellosis, a lot can be done to better the lot of Malaysians and improve the livestock and other sectors of the economy. The economic impact caused by colossal losses due to brucellosis all over Malaysia is a cause for more radical steps at eradicating the infection completely. The millions of dollars spend in compensation due to the disease will only be justified if it is completely eradicated. With the successful eradication of brucellosis money which would have been lost can be ploughed into the economy to develop the livestock industry more and ensure maximum food security for the nation and safe guard the health of the public. Strategic steps must aim at stopping all means of entry of the infection into the country especially from endemic countries when importing livestock in order to reap the fruits of the eradication policy.

\section{Conclusion}

About 30 years after the commencement of the eradication policy for brucellosis and the implementation of the compensation scheme, Malaysia is still endemic for brucellosis. The eradication policy needs to be reinforced with measures that will guard against all risk factors for brucellosis at all levels and farmers need to be more compensated for the total cost of animals lost or provided with full insurance schemes. Small ruminants seem to be more susceptible to brucellosis than the large ruminants but this needs further investigation and increasing the number of imported animals could increase the seroprevalence rate of brucellosis. Although eradication may be considered expensive but it is estimated that $\$ 7$ is saved for every $1 \$$ spend on eradication of brucellosis (Acha \& Szyfres, 2003). Eradication may be costly but not eradicating is even costlier.

\section{Acknowledgements}

The Department of Veterinary Services of Malaysia Headquarters, Putrajaya and all the state offices. All the laboratory staff of the Melaka Veterinary regional laboratory and the Veterinary Research Institute, Ipoh, Malaysia.

\section{Competing interests}

Authors declare that they have no competing interests.

\begin{tabular}{llr}
\hline www. veterinaryworld.org & Veterinary World, Vol.5 No.7 July 2012 & 402
\end{tabular} 


\section{References}

1. Verger, J.M., Grimont, F., Grimont, P.A. and Grayon, M. (1987) Taxonomy of the genus Brucella. Ann. Inst. Pasteur Microbiol. , 138: 235-238.

2. Scholz, H., Hubalek, Z., Sedlacek, I., Vergnaud, G., Tomaso, H., Al Dahouk, S., Melzer, F., Kampfer, P., Neubauer, H., Cloeckaert, A., Maquart, M., Zygmunt, M., Whatmore, A., Falsen, E., Bahn, P., Gollner, C., Pfeffer, M., Huber, B., Busse, H. and Nockler, K. (2008) Brucella microti sp. nov., isolated from the common vole Microtus arvalis. Int J Syst Evol Microbiol, 58:375 - 382. doi:10.1099/ijs.0.65356-0.

3. Scholz, H.C., Nockler, K., Gollner, C., Bahn, P., Vergnaud, G., Tomaso, H., Al Dahouk, S., Kampfer, P., Cloeckaert, A., Maquart, M., Zygmunt, M.S., Whatmore, A.M., Pfeffer, M., Huber, B., Busse, H.J. and De, B.K. (2010) Brucella inopinata sp. nov., isolated from a breast implant infection. Int J Syst Evol Microbiol, 60: 801-808. doi: ijs.0.011148-0.

4. Seleem, M.N., Boyle, S.M. and Sriranganathan, N. (2010) Brucellosis: A re-emerging zoonosis. Veterinary Microbiology, 140: 392-398. Doi: 10.1016/j.vetmic. 2009.06.021.

5. Foster, G., Osterman, B., Godfroid, J., Jacques, I. and Cloeckaert, A. (2007) Brucella ceti sp. nov. and Brucella pinnipedialis sp. nov. for Brucella strains with cetaceans and seals as their preferred hosts. Int $J$ Syst Evol Microbiol, 57: 2688 - 2693.

6. Acha, N.P. and Szyfres, B. (2003) Zoonoses and Communicable Diseases Common to Man and Animals. Pan American Health Organization (PAHO), Washington, D.C.

7. Akhtar, R., Chaudhry, P.Z.I., Shakoori, P.A.R., Ahmad, M.u.D. and Aslam, A. (2010) Comparative efficacy of conventional diagnostic methods and evaluation of polymerase chain reaction for the diagnosis of bovine brucellosis. Vet. World, 3: 53-56.

8. Priyantha, M.A.R. (2011) Identification of biovars of Brucella abortus in aborted cattle and buffaloes herd in Sri Lanka. Vet. World, 4: 542-545. Doi: 10.5455/vetworld.2011.542-545

9. Ghodasara, S.N., Roy, A. and Bhanderi, B.B. (2010) Comparison of Rose Bengal Plate Agglutination, Standard tube agglutination and Indirect ELISA tests for detection of Brucella antibodies in Cows and Buffaloes. Vet. World, 3: 61-64.

10. Deqiu, S., Donglou, X. and Jiming, Y. (2002) Epidemiology and control of brucellosis in China. Veterinary Microbiology, 90: 165-182.

11. Zinsstag, J., Roth, F., Orkhon, D., Chimed-Ochir, G., Nansalmaa, M., Kolar, J. and Vounatsou, P. (2005) A model of animal-human brucellosis transmission in Mongolia. Preventive Veterinary Medicine, 69: 77-95. Doi: 10.1016/j.prevetmed.2005.01.017.

12 Pappas, G., Papadimitriou, P., Akritidis, N., Christou, L., \& Tsianos, E. V. (2006). The new global map of human brucellosis. The Lancet Infectious Diseases. 6(2): 91-99.
13. Joseph, P. G. (1971). Major Bacterial diseases in Malaysia, their prevalence, detection and control. Paper presented at the Fifth FAO Regional Conference on Animal Production and Health in the Far East, Kuala Lumpur.

14. Bahaman, A. R., Joseph, P. G., \& Siti-Khairani, B. (2007). A Review of the Epidemiology and Control of Brucellosis in Malaysia. J. Vet. Malaysia. 19(1): 1-6.

15. Joseph, P. G. (1987). Brucellosis in Malaysia. Kuala Lumpur: Department of Veterinary Services, Ministry of Agriculture, Malaysia.

16. Anon. (2011). Malaysia: Livestock Pupulation 20052010. Retrieved 21-11-2011, 2011, from http://www. dvs.gov.my/c/document_library/get_file?uuid=2ddf 02a7-bb06-4212-8cfa-c6a8c323aa4e\& groupId $=28711$.

17. Bamaiyi, P. H., Hassan, L., Siti-Khirani, B., Adzhar, A., \& Rachmat, R. F. N. (2010, 30th July-1st August, 2010). The Seroprevalence of Brucella melitensis in goats of Malaysia from year 2000 to 2008. Paper presented at the 22nd Veterinary Association of Malaysia Congress and 4th Wildlife Society of Zoo and Wildlife Medicine International Meeting, Kuala Lumpur, Malaysia.

18. Anka, M. S., Hassan, L., Adzhar, A., Rusli, R. H., \& Rachmat, R. F. N. (2010). Seroprevalence of Bovine Brucellosis in Peninsular Malaysia Between 2000 and 2009. Paper presented at the 22nd Veterinary Association of Malaysia Congress and 4th Society of Zoo and Wildlife Medicine International Meeting, Kuala Lumpur, Malaysia.

19. Bamaiyi, P. H., Hassan, L., Khairani-Bejo, S., Krishnan, N., Adzhar, A., Ramlan, M., Hamidah, N. H. M., Abdullah, N., Maizura, H., Khebir, B. V., \& Norsuhanna, M. M. (2011). Preliminary Findings on the Seroprevalence of Three Re-emerging Infections Among Farmers and Veterinary Technical Staff in Selangor and Negeri Sembilan, Malaysia. Malaysian Journal of Veterinary Research. 2(Supplement 1): 66.

20. Jama'ayah, M. Z., Heu, J. Y., \& Norazah, A. (2011). Seroprevalance of brucellosis among suspected cases in Malaysia. Malaysian J Pathol.33(1):31-34.

21. Shahaza, O., Khairani-Bejo, S., Zunita, Z., \& Bahaman, A. R. (2009). In-House Rose Bengal Plate Agglutination Test (RBPT) for a Rapid Diagnosis of Brucellosis in Goats in Malaysia. International Journal of Tropical Medicine. 4(3): 116-118.

22. Malaysia, S. (2011). Basic Population Characteristics of Malaysia by Administrative Districts. Retrieved 22-11-2011, 2011, from http://www.statistics.gov.my/ portal/download_Population/files/BPD/ad_2010.pdf.

23. Alton, G. G., Jones, L. M., Rangus, R. G., \& Verger, J. M. (1988). Techniques for the brucellosis laboratory. Institut National de la Recherche Agronomique, Paris, France: 63-129.

24. Field, A. (2009). Exploring Statistics Using SPSS (3rd ed.). London: SAGE publications.

25. Currencyconverter. (2011). Malaysian Ringgit(MYR) 
and United States Dollars Currency Exchange Rate Conversion Calculator. Retrieved 23-11-2011, 2011, from http://coinmill.com/MYR_USD. html\#MYR.

26. Kaufmann, A. F., Meltzer, M. I., \& Schmid, G. P. (1997). The economic impact of a bioterrorist attack: are prevention and postattack intervention programs justifiable? Emerg Infect Dis. 3(2): 83-94.

27. Pappas, G. (2010). The changing Brucella ecology: novel reservoirs, new threats. International Journal of Antimicrobial Agents. 36(Supplement 1): S8-S11. Doi:10.1016/j.ijantimicag.2010.06.013.

28. Al-Majali, A. M., Majok, A. A., Amarin, N. M., \& AlRawashdeh, O. F. (2007). Prevalence of, and risk factors for, brucellosis in Awassi sheep in Southern Jordan. Small Ruminant Research. 73(1-3): 300-303. Doi: 10.1016/j.smallrumres.2007.02.002.

29. Guildford, J. P. (1973). Fundamental Statistics in Psychology and Education. In (5th ed.). NewYork: McGraw-Hill.

30. El Sherbini, A., Kabbash, I., Schelling, E., El Shennawy, S., Shalapy, N., Elnaby, G. H., Helmy, A. A., \& Eisa, A. (2007). Seroprevalences and local variation of human and livestock brucellosis in two villages in Gharbia Governorate, Egypt. Transactions of the Royal Society of Tropical Medicine and Hygiene. 101(9): 923-928.

31. Omer, M. K., Skjerve, E., Holstad, G., Woldehiwet, Z., \& Macmillan, a. P. (2000). Prevalence of antibodies to Brucella spp. in cattle, sheep, goats, horses and camels in the State of Eritrea; influence of husbandry systems. Epidemiology and infection. 125: 447-453.

32. Muma, J. B., Samui, K. L., Siamudaala, V. M., Oloya, J., Matope, G., Omer, M. K., Munyeme, M., Mubita, C., \& Skjerve, E. (2006). Prevalence of antibodies to Brucella spp. and individual risk Factors of Infection in Traditional Cattle, Goats and Sheep Reared in Livestock-Wildlife Interface Areas of Zambia. Tropical Animal Health and Production. 38: 195-206.

33. Holt, H., Eltholth, M., Hegazy, Y., El-Tras, W., Tayel, A., \& Guitian, J. (2011). Brucella spp. infection in large ruminants in an endemic area of Egypt: crosssectional study investigating seroprevalence, risk factors and livestock owner's knowledge, attitudes and practices (KAPs). BMC Public Health. 11(1):341.

34. Kabagambe, E. K., Elzer, P. H., Geaghan, J. P., Opuda-Asibo, J., Scholl, D. T., \& Miller, J. E. (2001). Risk factors for Brucella seropositivity in goat herds in eastern and western Uganda. Preventive Veterinary Medicine. 52(2): 91-108. Doi: 10.1016/S0167-5877 (01)00251-3.

35. Mukhtar, F. (2010). Brucellosis in a high risk occupational group: seroprevalence and analysis of risk factors. Journal of Pakistan Medical Association. 60(12): 1031-1034.

36. Fathey, A. R., \& Moghney, A. (2004). A preliminary study on brucellosis on camels at Behira province. Assuit Univ Bull Environ Res. 7: 39-43.

37. Jones, P. W. (2011). Background Note: Malaysia. Retrieved 24-11-2011, 2011, from http://www.state. gov/r/pa/ei/bgn/2777.htm. 